\title{
Geographic Information System of Contraceptives Users in Samarinda Seberang Sub-District
}

\author{
Muhammad Renaldi Arianda \\ Software Enginering Technology, \\ Agricultural Polytechnic of \\ Samarinda, Samarinda, 75242, \\ Indonesia \\ muhamadrenaldiarianda@gmail.com
}

\author{
Ida Maratul Khamidah (i)* \\ Software Enginering Technology, \\ Agricultural Polytechnic of \\ Samarinda, Samarinda, 75242, \\ Indonesia \\ idamaratul@gmail.com \\ *Corresponding author
}

\author{
Nia Kurniadin (ㄹ) \\ Geomatics Technology, Agricultural \\ Polytechnic of Samarinda, \\ Samarinda, 75242, Indonesia \\ niakurniadin@gmail.com
}

Received: 2021-09-30; Revised: 2021-10-02; Accepted: 2021-11-08; Published: 2021-12-01

\begin{abstract}
Birth Control "Keluarga Berencana" (KB) is a government program designed to balance the needs and population. Birth Control is an attempt to measure the number of children and the desired birth spacing of children. Therefore, the Government launched a program or method to prevent and delay pregnancy. Therefore, the purpose of this study is to create a geographic information system for data collection of contraceptive users based on a website that is useful as a place to store data on contraceptive users and information maps as a benchmark for the achievement of Birth Control instructors in the area of Samarinda opposite. The results of this study that the existence of this geographic information system website, besides being able to assist the public in obtaining information about contraceptives, can also assist the work of Birth Control instructors in the regions, especially in the Samarinda Seberang area in recording Birth Control users in their working areas and as a step to help reduce paper use and modernization from the old system.
\end{abstract}

Keywords- Geographic Information System, Contraception, Birth Control, Children

\section{INTRODUCTION}

The Birth Control "Keluarga Berencana" (KB) program by the government is so that the family as a senior high schoolll unit of the nation's life is expected to accept the Senior high schoolll Happy and Prosperous Family Norm "Norma keluarga kecil bahagia dan Sejahtera" (NKKBS) which is oriented towards balanced growth.

Birth Control "Keluarga Berencana" (KB) is an attempt to measure the number of children and the desired birth spacing of children. Therefore, the government has launched a program or method to prevent and delay marriage (Bappenas, 2015). In the modern era like today, technology has greatly helped human life in carrying out work and information needs.

In the daily work activities of Birth Control instructors in the special area of Samarinda, they still do not have a digital data input system to input updated data on Birth Control users, a system for monitoring contraceptive users "Keluarga Berencana" (KB), and a system that stores documentation of Birth Control extension activities in the area

One way of presenting geographic data information is to use GIS (Geographical Information System), GIS is a special information system that provides managing data that has spatial information (spatial reference) or in a narrower sense, is a computer system It has the ability to build, store, manage, and show geographically referenced information (Julianti, 2018)

\section{LITERATURE REVIEW}

According to research conducted by (Soepomo, Kharistiani and Aribowo 2013) from Ahmad Dahlan University, they conducted a study entitled Geographic Information System for Mapping the Potential of WebBased High School/Vocational High Schools (Case Study: Kebumen Regency). The system created includes input, edit Senior High School/Vocational high School data, and determination of Senior High School/Vocational high School points and Senior High School/Vocational high School distances from a position based on a specified radius and can provide Senior High School/Vocational high School data information, namely displaying Senior High School/Vocational high School identities, teacher and employee data., student data, facility data, and UAN data as well as displaying the location of Senior High School/Vocational high School.

According to (Wirangga, Piarsa, and Purnawan 2014) from Udayana University from the research, he did entitle Application of Geographic Information Systems for Mapping the Location of a Restaurant in the Denpasar Region. In this journal, the purpose of this application is to search for web-based restaurants to make it easier for Balinese people or tourists to determine which restaurants they want to visit. The benefits of this application provide information about the location of restaurants in the 
Denpasar area and search for restaurant locations according to the criteria desired by visitors which can be accessed on the web via the internet.

Research conducted by (Zulkarnain, Sudarsono, and Nugraha 2015) from the University of Diponegoro entitled Utilization of WebGIS for Gas Station Distribution in Semarang City. The purpose of this study was to determine the distribution of gas stations in the city of Semarang and make it easier for users to find out the location of the nearest gas station. The benefit of this application is to provide information in the form of a map of the distribution of gas stations in the city of Semarang and also to provide information that can be accessed easily via the Web which can be accessed via the internet.

Research conducted by (Wijaya, Suprayogi, and Gustavianto 2016) from Diponegoro University with the title Application of Geographic Information Systems (GIS) for the Distribution of Web-Based Micro, Senior high schoolll, and Medium Enterprises (MSMEs) (Case Study: City of Salatiga). The purpose of this research is to create a Web-based application (MSMEs) in Salatiga City. And aims to provide an alternative data information search application to users about the distribution of MSMEs in Salatiga City

Research conducted by (Utomo, Yuwono, and Amarrohman 2017) entitled Application of Web and Android-Based Geographic Information System for Alternative Route Selection of Tourist Attractions (Case Study: Cibubur and Jungleland Tourism City, Bogor Regency). The purpose of this journal is to obtain alternative routes that can be passed to a tourist location based on the results of field surveys and the alternative route access process that has been proven to be traversable based on the survey results into a web-based GIS and thus provides information about alternative access routes that can be downloaded. by using a PC (Personal Computer) via the web or with a Senior High School Phone via Android, and also providing information to potential visitors to tourist sites to respond to available alternative routes if the main route offered by Google Map or Waze experiences congestion.

\section{A. Geographic Information Systems}

A geographic Information System is a computer system used to collect, examine, integrate, and analyze information relating to the earth's surface. The term geographic information contains the meaning of information about places located on the earth's surface, knowledge about the position where an object is located on the earth's surface, and information about information (attributes) found on the earth's surface, and information about information (attributes). found on the earth's surface whose position is given or known (Prahasta, 2014)

\section{B. Family Planing}

Definition of Birth Control "Keluarga Berencana" (KB) according to Law no. 10 of 1992 concerning Population Development and Development of Prosperous Families is an effort to increase awareness of community participation through maturing the age of marriage (PUP), birth control, fostering family resilience, increasing the welfare of senior high schoolll, happy and prosperous families (Sujiyantini, 2009).

\section{Leaflet}

A leaflet is generally an open source javascript library that is useful for building web-based interactive map applications. Leaflet supports mobile platforms and desktop platforms, HTML5 and CSS3 as well as OpenLayer and Google Maps API which are javascript libraries for building map applications that are very popular today.

A leaflet is also capable of displaying layers from geojson files, styling, and creating interactive layers such as displaying markers that display pop-up information when clicked.

\section{JavaScript}

A popular scripting language on the internet and works in most popular browsers such as Internet Explorer (IE), Mozilla Firefox, Netscape, and Opera. Javascript code can be inserted into web pages using script tags (Sunyoto, 2007)

\section{E. Google map direction}

Directions service access is asynchronous because the Google Maps API needs to make a call to an external server. Therefore, you need to pass the callback method to execute after the request is completed. The callback method should process the results. Pay attention, service Directions may return more than one possible itinerary as a separate routes array (Anugerah , 2016)

\section{F. Flowchart}

A flowchart is a method to describe the stages of problem-solving (procedures) along with the flow of data with symbols easy-to-understand standards. The main purpose of using flowcharts is to simplify a series of processes or procedures to make easier user's understanding of the information. To that end, design a Flowcharts must be concise, clear, and logical (Ridlo, 2017)

\section{G. Data Flow Diagram}

DFD is a graphical representation that describes the flow of information and the transformation of information that is applied as data that flows from the input (input) and output (output). DFD can be used to represent a system or software at several levels of abstraction (Rossa and Shaluddin, 2018)

\section{H. Method Waterfall}

Information system development model systematic and sequential which has several stages such as Requirements analysis and definition, System and software design, Implementation and unit testing, Integration and system testing, Operation and maintenance (Sasmito and Wiro, 2017) 


\section{Spatial and Non Spatial data}

Spatial and non-spatial data are data used by geographic information systems. Where spatial data is data in graphic form that shows space locations or places on the earth's surface as well as non-spatial data that provides an explanation or description of each object on the earth's surface (Ariandi and Agustini, 2016)

\section{j. Vektor data}

There are three types of vector data, namely: Point, Includes all graphic or geographic objects associated with coordinate pairs (x,y). Line, are all linear elements that are built using straight line segments formed by two or more coordinate points, Polygon, is a closed object that has an area. Polygons can be represented in various ways in a vector data mode (Awangga, 2019)

\section{k. Mysql}

MySQL is a DBMS (Database Management) application System) which is widely used by web application programmers. all information is stored in one field area, which sometimes the data in it is very difficult to access. MySQL is a program that can be used as a database and is one of the software for many database servers used (Orlando 2017).

\section{RESEARCH METHOD}

\section{A. Tools and Materials}

The tools used in the research:

1. Hardware
a. Laptop ASUS X540L INTEL INSIDE CORE i3 Processor (500 5U, $2.0 \mathrm{GHz}$ )
b. Handphone Xiaomi Redmi Note 8
c. Mouse Logitech M331 Silent

2. Software
a. Xampp
b. Sublime Text
c. MySQL Database
d. Leaflet
e. Bootstrap

3. The materials used are as follows:

Data on people using contraceptives in the Samarinda Seberang area "Badan Kependudukan dan Keluarga Berencana Nasional” (BKKBN)

\section{B. Research Procedures}

The stages of the research procedure used the waterfall model. This model takes a systematic or sequential approach in building a flow of research procedures. Which can see in Picture 1

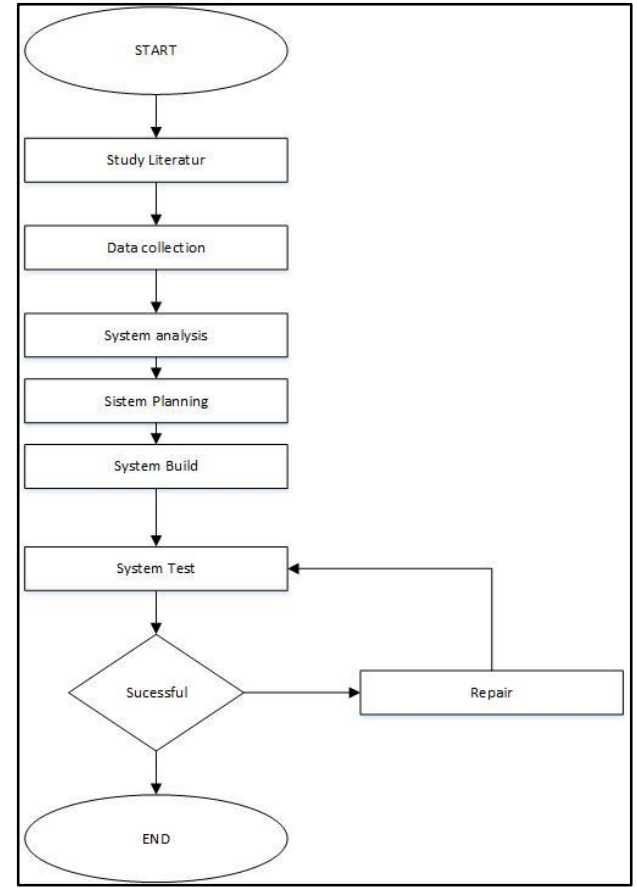

Picture 1. Flowchart of Research Procedures

The following is an explanation of the stages of the research procedure:

1. Literature study

Conducting research preparations whose preparation is the same as other research but the sources and methods of data collection are by taking data in the library, reading, taking notes, and processing research materials 2. Data Collection

Collect direct data and systematically compile the necessary data such as what types of Birth Control "Keluarga Berencana" (KB) devices are used and which people are in the area who use these contraceptives

3. System Analysis

The decomposition of a complete information system into its component parts, with a view to identifying and evaluating problems and obstacles that occur and the expected needs so that improvements can be proposed.

4. System Design

The system design is presented in the form of Data Flow Diagrams (DFD). Data Flow Diagrams (DFD) start from the most common form, namely context diagrams (context diagrams), then from this context diagram are derived into more detailed forms, system design helps in hardware and system requirements and also helps in defining architecture system.

5. System Build

The explanation of the system work carried out is to create a mapping information system application with the web that runs well, namely by the first step providing information maps that can be obtained from maps, websites containing data collection on contraceptive use, and combining maps with websites so that they become a web-based mapping information system. 


\section{System testing}

System testing is carried out to observe the results of execution through test data and check the functionality of the software. So evaluating only from the outside (interface) functionality, without knowing what actually happened in the detailed process (only knowing input and output).

\section{System Design}

1) DFD (Data Flow Diagram)

DFD level 0 is a diagram that only displays and describes the data flow mechanism of a system in general. Following is DFD (Data Flow Diagram) level 0, which can be seen in Picture 2

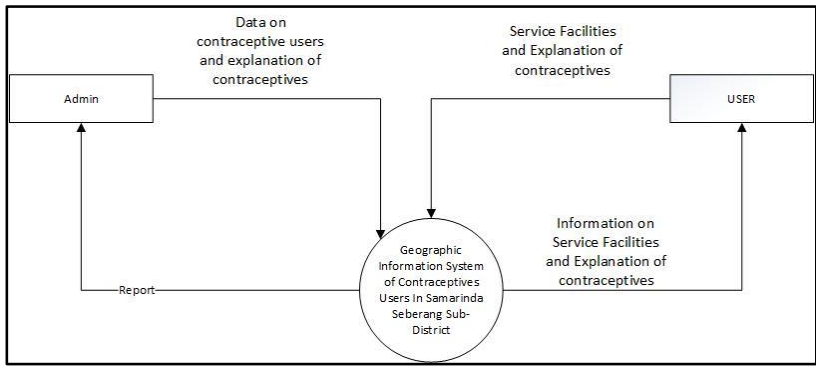

Picture 2. DFD level 0

2. DFD(Data Flow Diagram) level 1

The following is a level 1 DFD (Data Flow Diagram) Geographic Information System for contraceptives in the region Samarinda Seberang Sub District, which can be seen in Picture 3

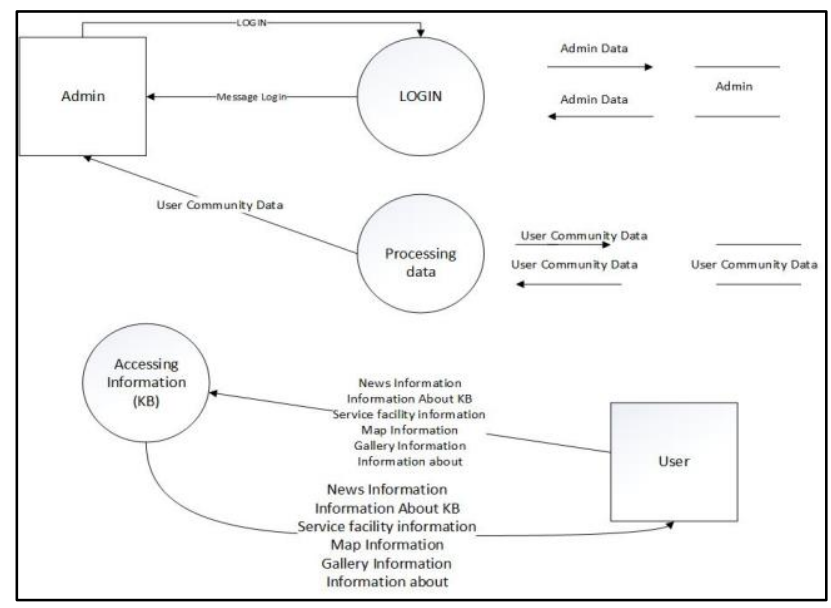

Picture 3. DFD level 1

\section{DFD(Data Flow Diagram) level 2}

The following is a level 2 DFD (Data Flow Diagram) resulting from the decomposition of the process of accessing Birth Control information, it can be seen in Picture 4

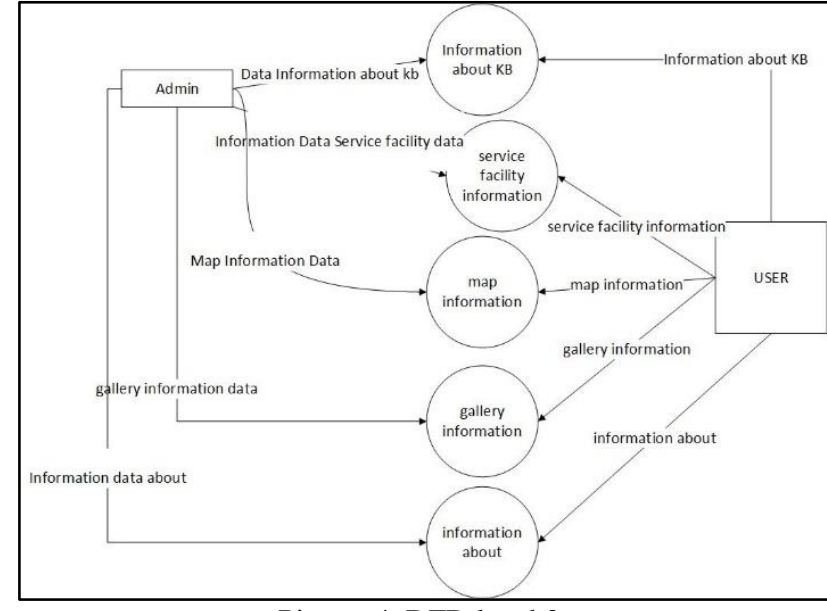

Picture 4. DFD level 2

\section{RESULT AND DISCUSSION}

1) Login page

Login page for admin, before admin enters dashboard page, an admin must log in by entering correct username and password, can be seen in Picture 5

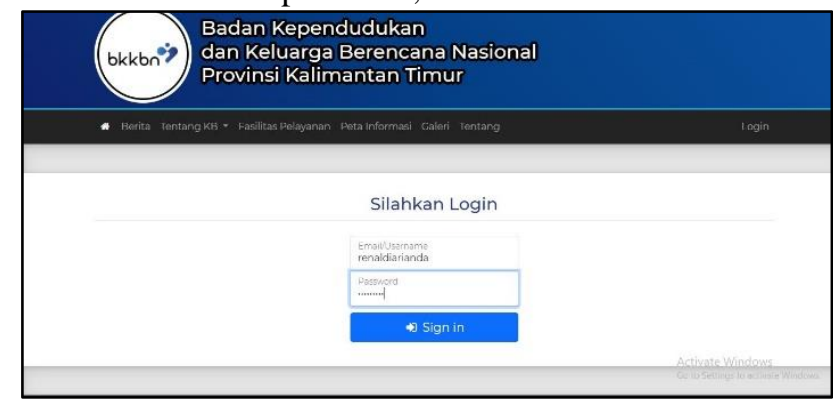

Picture 5. Login Page

2) Home page

The home page displays the number of contraceptive users and the latest news. it can be seen in Picture 6

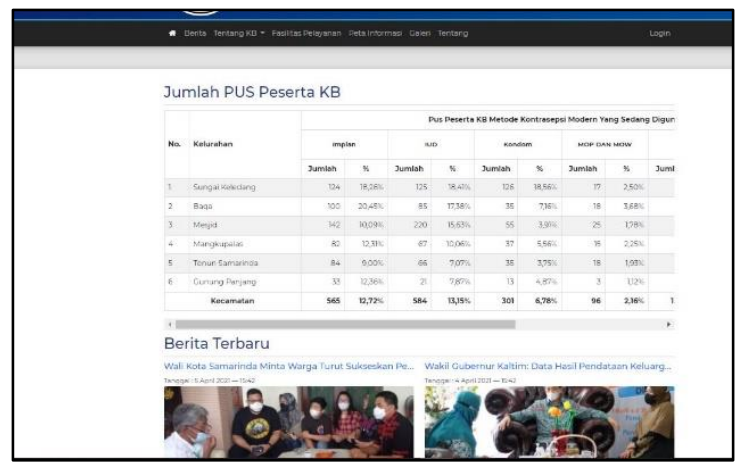

Picture 6. Home page

3) About $\mathrm{KB}$

The page about Birth Control "Keluarga Berencana" (KB) displays the types of contraceptives along with an explanation of each method of contraception. Can be seen in Picture 7 


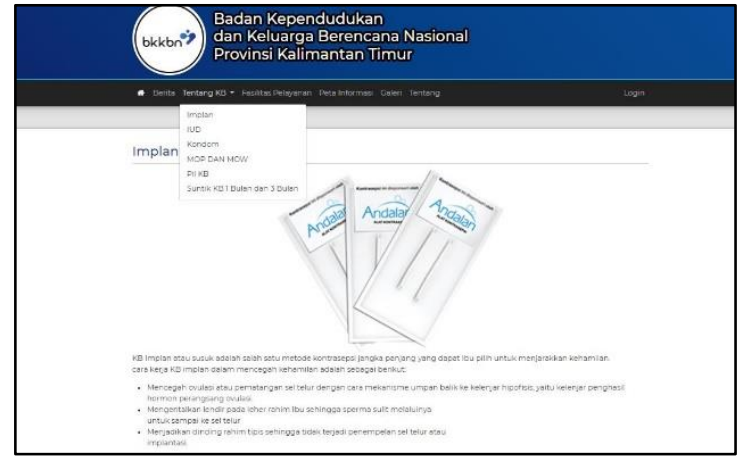

Picture 7. About KB

4) Service facilities

The service facilities page displays information about health facilities that can serve the installation of contraceptives. It can be seen in Picture 8 .

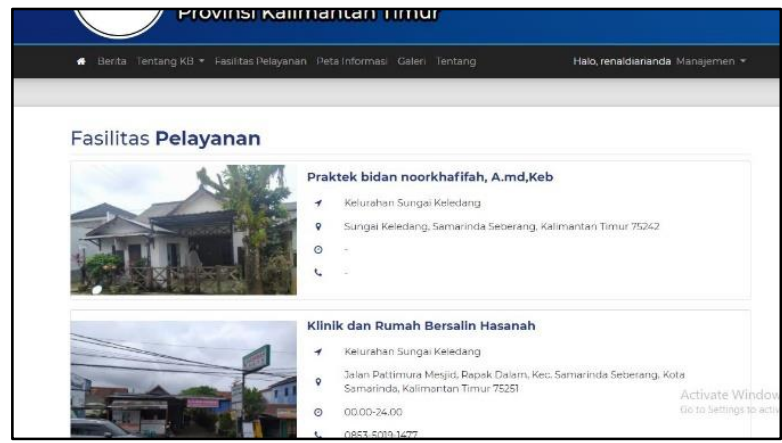

Picture 8. Service facilities

5) Information map page

The information map displays information about the number of contraceptive users in the data collection area, displays the point of service for installing contraceptives, and displays 3 color changes as 3 levels of the number of contraceptive use. if the number of users is below 600 people, the regional information map will be red because it is felt that the number of users is still senior high schools. the user then the map will be green, which means the user feels a lot. The indicator numbers are obtained from the "Keluarga Berencana" (KB) extension samarinda Seberang, it can be seen in Picture 9.

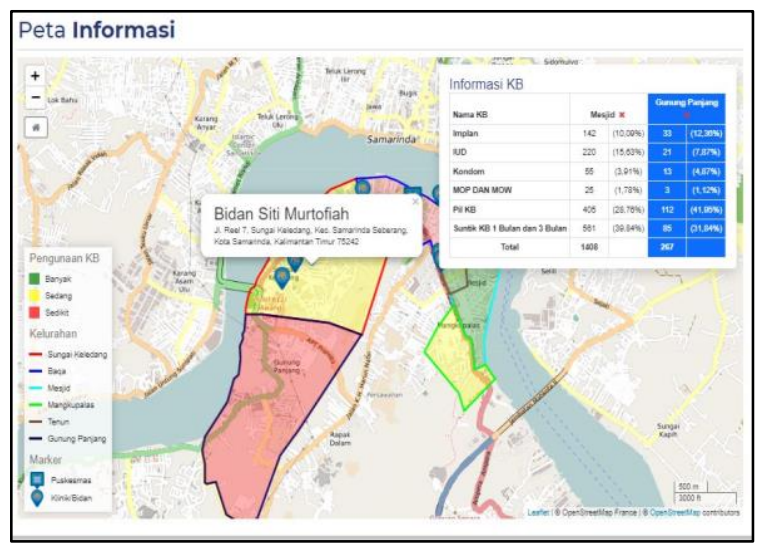

Picture 9. Information map page
6) Display of added user community data In this view is the process of adding user community data by the admin. Can be seen in Picture 10.

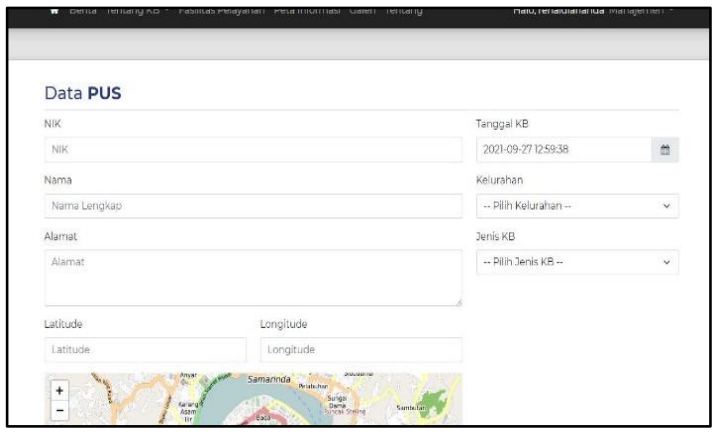

Picture 10. Display of added user community data

7) About page

This view displays about this website. It can be seen in Picture 11.

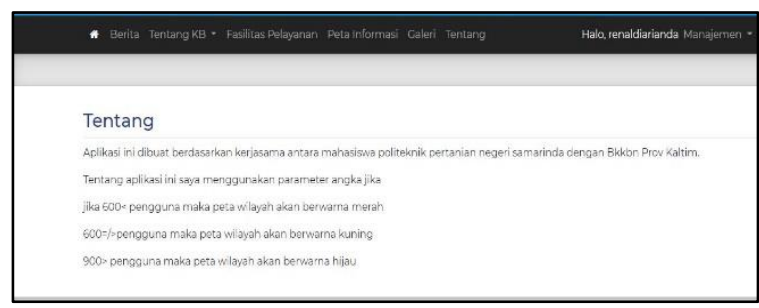

Picture 11. About page

8) Gallery page

In this view, the gallery displays as a medium for documenting the activities carried out, it can be seen in Picture 12.

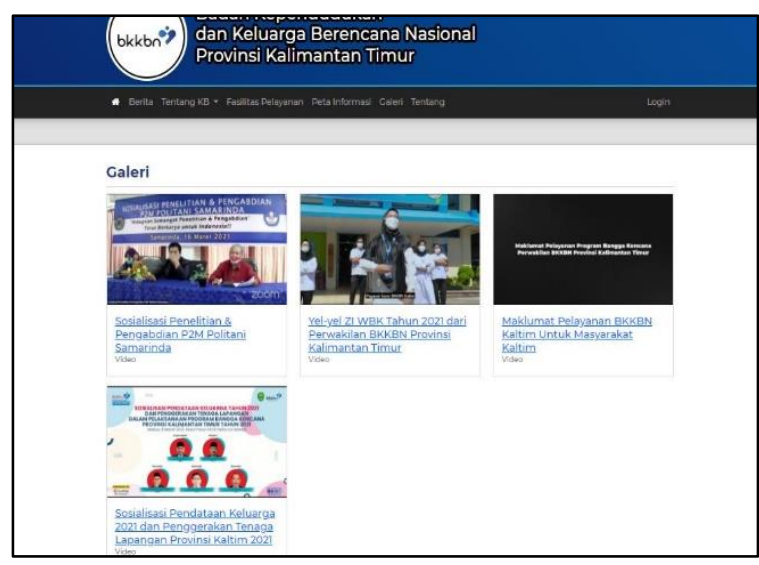

Picture 12. Gallery page

9) Data processing of contraceptive information In this view, data processing of contraceptive information by admin can be seen in Picture 13 


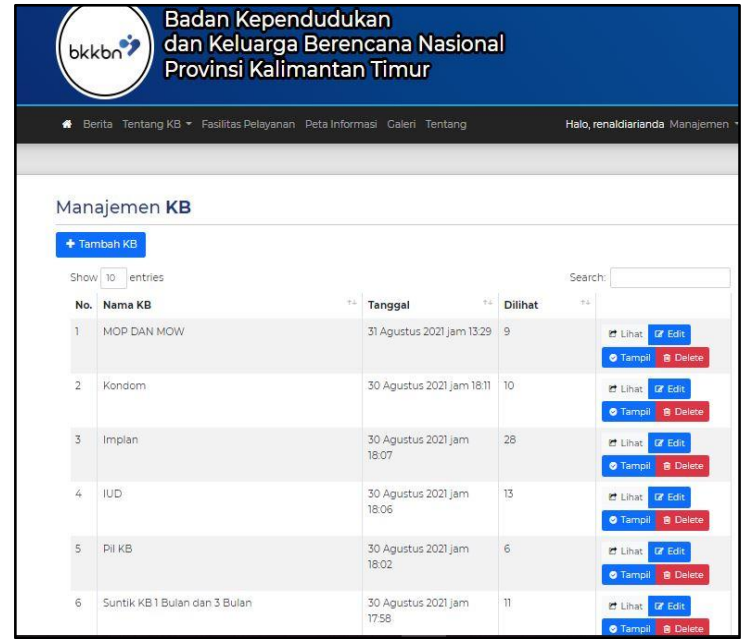

Picture 13 data processing of contraceptive

10) Processing data of service facility information In this view, the data processing of service facility information by the admin can be seen in Picture 14

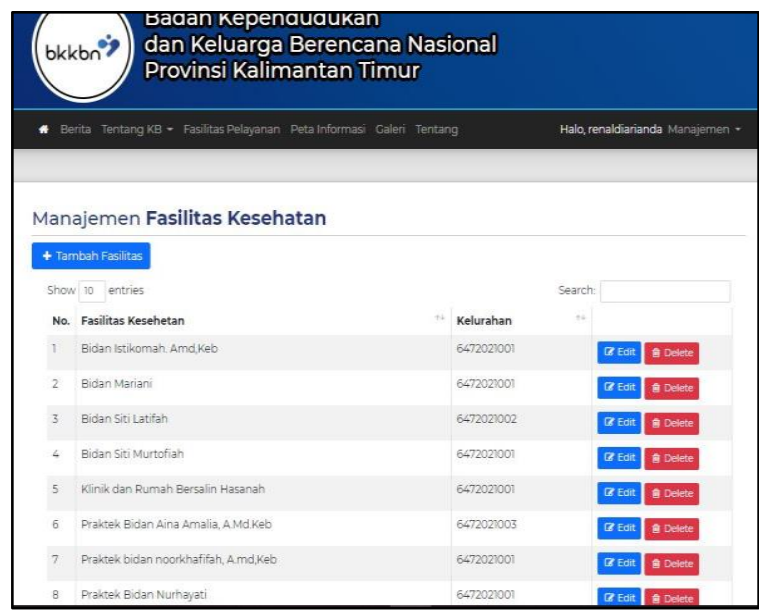

Picture 14 Service facility data processing

\section{CONCLUSION}

Based on the previous description as well as the results and analysis of the Geographic Information System for Contraceptive Users in Samarinda Seberang District, it can be concluded that this geographic information system is a tool for family planning extension workers in carrying out their daily work and helps users to get more information about the family planning program. Planning" (KB) which is the point of service facilities that can be visited to use the "Family Planning" (KB) contraceptive in Samarinda. In the future, this geographic information system can still be developed in accordance with the development of user requirements specifications. This application can be developed with a more attractive appearance. This application is made based on mobile (Android) so it can be used anywhere

\section{REFERENCES}

Anugerah A., Astuti I. and Kridalaksana. 2016. Web-Based Geographic Information System Mapping of Samarinda Typical Souvenir Shop Locations: Mulawarman Informatics: Scientific Journal of Computer Science.

Ariandi, M., \& Agustini, E. P. 2016. Spatial and Non-spatial Data on Population Distribution in Rambutan District. APTIKOM National Seminar, 2(1), 28-29.

Awangga, R. M. 2019. Introduction to geographic information systems: history, definitions and basic concepts. Retrieved

BAPPENAS. 2015. Birth Control, Journal of Nursing.

Gustavianto, M., Suprayogi, A. and Wijaya, A. 2016. Application of Web-Based Geographic Information System (Sig) Distribution of Micro, Senior high schoolll and Medium Enterprises (MSMEs) (Case Study: Salatiga City), Journal of Geodesy Undip, 5(1), pp. 49-56.

Julianti, M. R., Budiman, A. and Patriosa, A. 2018. The Design of a Geographic Information System for Mapping Pharmacy Locations in the Bogor City Area, Web-Based, Global Sisfotek Journal, 8(1), pp. 13-19.

Orlando, Erik. 2017. "Application for Leave Application for Human Resources Management Using PHP and MYSQL (Case Study at PT.INTRODUCTION)."Scientific Journal of COMPUTING16(3):275-84.

http://ejournal.jakstik.ac.id/index.php/komput/article/ viewArticle/2336.

Prahasta Eddy. 2014. Geographic Information System Basic Concepts (Geodesy \& Geomatics Perspective). Bandung Informatics.

Ridlo I.A. 2017. Panduan Pembuatan Flowchart. 1-27.

Rossa and Saladin. M. 2018. "Structured and ObjectOriented Software Engineering". Informatics Bandung: Software Engineering.

Sasmito. and Wiro G. 2017. Application of the Waterfall Method in the Design of Industrial Geographic Information Systems in Tegal Regency. Journal of Informatics:Journal of IT Development (JPIT) 2 (1): 6-12.

Soepomo, P. 2014. Geographic Information System for Mapping Potential Web-Based High Schools (Case Study: Kebumen Regency), JSTIE (Journal of Bachelor of Informatics Engineering) (E-Journal), 2(1), pp. 41-49. doi:10.12928/jstie.v2i1.2600.

Utomo, T., Yuwono, B. and Amarrohman, F. 2017. Application of Web and Android-Based Geographic Information System for Selection of Alternative Paths to Tourism Places (Case Study: Cibubur and Jungleland Tourism City, Bogor Regency), Journal of Geodesy Undip, 6 (2), pp. 1-11.

Wirangga, I. W. Y., Piarsa, I. N. and Purnawan, I. K. A. 2016. Application of Geographic Information System for Mapping the Location of a Restaurant in Denpasar Area, Merpati, 2(2), pp. 238-245. DOI: 10.24843/JIM. 
Zulkarnain, S., Sudarsono, B. and Nugraha, A. 2015. Utilization of WebGIS for Mapping the Distribution of Gas Stations in Semarang City, Journal of Geodesy Undip, 4(3), pp. 19-25. 